\title{
Manager Overconfidence and Cost Stickiness
}

\author{
Pan Keke ${ }^{1}$ \\ ${ }^{1}$ Beijing Jiaotong University, Beijing, China
}

\begin{abstract}
China market economy is in a new period of structural deceleration. Factors, such as fierce external competition and the advancement of the globalization process have put Chinese companies under enormous development pressure. Cost management is very important for improving the utilization rate of resources, the core competitiveness of an enterprise, and achieving the net profit target set by the enterprise. The basis study of cost management is the cost form. After the stickiness of costs is proposed, it has been widely concerned by academia and practice. Managers are the decision-makers of business activities and internal information disclosure. The current shareholding structure of the Chinese government's macro-control has formed an "insider control" phenomenon, which highlights the importance of managers. Overconfidence of the managers can strongly impact on the manager's decision-making. Based on this, it is of great significance to study the influence of managers' overconfidence on the cost stickiness. This paper uses the data of Shanghai and Shenzhen A shares manufacturing companies from 2014 to 2018 to verify the existence of cost stickiness, and then studies the influence of managers' overconfidence on the cost stickiness. The study found that there is a phenomenon of cost stickiness in listed companies in China's manufacturing industry. More over, managers' overconfidence can aggravate the problem of cost stickiness of enterprises. The innovation of the research is as following. Firstly, it enriches the research perspective of the sticky motivation of costs. Secondly, the study extends the research of managers' overconfidence to the field of cost decision-making.
\end{abstract}

\section{Introduction}

China market economy is in a new period of structural deceleration. Chinese enterprises are facing tremendous pressure for survival and development under the fierce external competition. Strengthening cost management and improving the efficiency of resource allocation are conducive to improving the company's core competitiveness. Then achieving net profit goals. Studying cost patterns is the basis for cost management. The traditional cost morphology theory holds that costs and volume change in direct proportion within a certain range. In recent years, with the continuous deepening of cost research, the study of the phenomenon of cost stickiness has arouse wide concern in academia and practice. Compared with traditional cost patterns, cost stickiness is not symmetrical, that is, the marginal decrease in expenses when the business volume decreases is less than the marginal increase in expenses when the business volume increases [1]. At present, the research on cost stickiness mainly focuses on its influencing factors and motivations. The research on the motivation of cost stickiness is helpful for enterprise owners and managers to find problems in the process of cost management and improve enterprise performance.

The government's macro-control mechanism is the institutional environment faced by Chinese enterprises. Under the current regulations of shareholding structure, the phenomenon of "internal control" is more serious. "Insider control" mainly refers to that enterprise managers control a large amount of resources and internal information of enterprises, and play a decisive role in important decisions of enterprises. Therefore, it is necessary to study cost management from the perspective of enterprise managers. At present, scholars at home and abroad have used a variety of theories such as efficiency concept, managerial agency theory and contract theory to study the motivation of cost stickiness. However, the above research implies that manangers are rational without considering the psychological behavior of managers. Behavioral finance theory questions the assumption of traditional rational people. The theory believes that people's behavior is not completely rational. Especially, managers often overestimate their own ability level and the accuracy of the information they have when they make decisions. Based on that, it is of practical significance to study the influence of managers' overconfidence on the stickiness of corporate expenses.

This paper uses the data of Shanghai and Shenzhen A shares manufacturing companies from 2014 to 2018 to verify the existence of fee stickiness, and then studies the impact of managers' overconfidence on fee stickiness. The research significance of this article is mainly as follows For the motivation of building: Firstly, it theoretically enriches the research perspective of cost stickiness drivers, and extends the research of managers' overconfidence to the field of cost decision-making. Secondly, in practical 
sense, it not only helps strengthen the cost management of the enterprise, but also helps remind managers to avoid overconfident decision-making mistakes.

\section{Research design}

\subsection{Research hypothesis}

In 2003, Anderson et al. firstly proposed the concept of cost stickiness, that is, the marginal decrease in expenses when the business volume decreases is less than the marginal increase in expenses when the business volume increases. Due to adjustment costs, managerial overconfidence and agency problems, stickiness of cost is a common phenomenon in many companies. Listed manufacturing companies often hold fixed assets of greater value and usually sign early labor contracts with workers, which cause adjustment costs are huge. The separation of management rights and ownership makes the agency problem prominent. For the motivation of building an enterprise empire and holding a lot of resources, $m$ This showsanagers will not reduce the amount of resources held in a timely manner when the business volume of the enterprise declines.

Based on the above analysis gives hypothesis 1: The phenomenon of cost stickiness exists in Chinese manufacturing listed companies.

The relationship between managers' overconfidence and cost stickiness can be analyzed from two aspects: the motivation of cost stickiness and the corporate behavior driven by managers' overconfidence. One side, the managers' optimistic expectations are an important factor in generating cost stickiness. Managers' optimistic expectations mean that when the business volume of a company declines, managers are optimistic about the company's future sales under the influence of "better than average effect" and attribution bias. Therefore, under the psychological hint of overconfidence, managers will choose to hold idle resources. On the other hand, overconfident managers, driven by the willingness mechanism, financial strength mechanism and capability mechanism, will also maintain an optimistic attitude towards the company's sales, thereby increasing the degree of cost stickiness.

Based on the above analysis gives hypothesis 2 of this paper is proposed: the manager's overconfidence is positively correlated with the enterprise's cost stickiness, that is, the stronger the manager's overconfidence, the greater the firm's cost stickiness.

\subsection{Sample selection}

Choosing companies in the same industry when studying the stickiness of costs can improve the comparability of cost-profit models among companies. The competitive environment in the manufacturing industry is fierce, which can mitigate the impact of monopoly prices on income (Weiss, 2010). Therefore, this article selects the 2014-2018 Shanghai and Shenzhen A shares manufacturing listed companies as the research object, excluding the following companies on this basis:
(1) In order to avoid the IPO effect, we exclude companies with a listing period of less than two years;

(2) Eliminate companies with missing variable data;

(3) Eliminate ST and ST* companies;

(4) Censoring the samples whose changes in operating income and operating costs are less than $5 \%$.

\subsection{Variable definitions}

2.3.1 Cost stickiness: Drawing on the research of Anderson et al. (2003), this paper uses the relationship between the rate of change of cost and the rate of change of operating income to measure cost stickiness.

$$
\ln \left(\frac{S_{S G A_{i, t}}}{S_{i, t-1)}}\right)=\beta_{0}+\beta_{1} \ln \left(\frac{\text { Sales }_{i, t}}{\text { Sales }_{i, t-1)}}\right)+\beta_{2} \times
$$

$\operatorname{DecrDum}_{i, t} \times \ln \left(\frac{\text { Sales }_{i, t}}{\text { Sales }_{i, t-1)}}\right)+\varepsilon_{i, t}$ (1)

$\ln \left(\frac{S G A_{i, t}}{S G A_{i, t-1)}}\right)$ is the logarithm of the ratio of current period sales expenses and management expenses to that of last period. $\ln \left(\frac{\text { Sales }_{i, t}}{\text { Sales }_{i, t-1)}}\right)$ is the logarithm of the ratio of current period operating income to that of last period. DecrDum $_{i, t}$ is a virtual variable, when the operating income of this year is lower than last year, the value is 1 , otherwise it is $0 . \beta_{1}$ is the growth rate of sales and management expenses, when operating income rises by $1 \%$. When the operating income declines, DecrDum ${ }_{i, t}=$ 1. It is easy to know, $\beta_{1}+\beta_{2}$ is the declining rate of sales and management expenses when operating income declines by $1 \%$. When $\beta_{1}>\beta_{1}+\beta_{2}$, it can prove the existence of cost stickiness. It also can be proved when the $\beta_{2}$ significantly less than 0 .

2.3.2 Manager's overconfidence: Drawing on Fuxiu Jiang and other measurement methods, this paper mainly uses executive relative salary to measure managers' overconfidence $($ Oconf $)[4]$. The higher the relative salary of the managers, the higher the status and the stronger the control. Managers are easy to be overconfident. The relative salary of the top three directors, supervisors or senior managers to the entire manager salary level is used to measure the degree of managerial overconfidence.

2.3.3 Control variables: Dawing on the relevant literatures of many scholars on the study of cost stickiness. $\mathrm{T}$, this paper selects asset intensity $\left(\operatorname{Ain}_{i, t}\right)$ and the change of operating income for two consecutive periods $\left(\operatorname{SucDec}_{i, t}\right)$ as control variables.

a) Asset intensity: Enterprises with greater asset intensity hold more assets. When the business volume declines, companies cannot reduce the cost and investment in time. Therefore, the elasticity of enterprises' downward adjustment of costs will be correspondingly reduced, which will lead to cost stickiness. This article uses the ratio of the company's total assets to operating income to measure capital intensity.

b) Changes in operating income for two consecutive periods: The study of Banker and other scholars found that when the operating income of a company drops for two consecutive periods, managers will realize the mistakes made in the previous judgment of 
sales, which will make managers lower their expectations for future performance. Therefore, managers will actively reduce enterprise costs, and can curb cost stickiness to a certain extent. Take 1 when the operating income drops for two consecutive years, otherwise take 0 .

\subsection{Research model}

Equation 1 is a measure of the cost stickiness variable, which can be used to verify hypothesis 1 . When $\beta_{2}$ is significantly less than 0 , it indicates that there is cost stickiness. To test hypothesis 2 can add the multiplication term of manager confidence and operating income change rate and control variables to Equation 1 to get Equation 2 . If the manager's overconfidence will increase the company's cost stickiness, then the $\beta_{3}$ in formula 2 should be significantly less than zero.

$\ln \left(\frac{S_{S G A_{i, t}}}{\operatorname{SGA}_{i, t-1)}}\right)=\beta_{0}+\beta_{1} \ln \left(\frac{\text { Sales }_{i, t}}{\text { Sales }_{i, t-1}}\right)+\beta_{2} \times$ DecrDum $_{i, t} \times \ln \left(\frac{\text { Sales }_{i, t}}{\text { Sales }_{i, t-1}}\right)+$ $\beta_{3} \times \operatorname{DecrDum}_{i, t} \times \ln \left(\frac{\text { Sales }_{i, t}}{\text { Sales }_{i, t-1}}\right) \times$ Oconf $+\beta_{4} \times$ DecrDum $_{i, t} \times$ $\ln \left(\frac{\text { Sales }_{i, t}}{\text { Sales }_{i, t-1}}\right) \times$ Ain $_{i, t}+\beta_{5} \times$ DecrDum $_{i, t} \times \ln \left(\frac{\text { Sales }_{i, t}}{\text { Sales }_{i, t-1}}\right) \times$ SucDec $_{i, t}+$ $\sum$ Year $+\varepsilon_{i, t}$

Table1. Definition and calculation of variables

\begin{tabular}{|c|c|c|c|}
\hline $\begin{array}{l}\text { Variable } \\
\text { type }\end{array}$ & Variable & Symbol & $\begin{array}{l}\text { Calculation } \\
\text { method }\end{array}$ \\
\hline $\begin{array}{l}\text { Explained } \\
\text { variable }\end{array}$ & $\begin{array}{l}\text { Change rate of } \\
\text { sales and } \\
\text { management } \\
\text { expenses }\end{array}$ & $\frac{S G A_{i, t}}{S G A_{i, t-1)}}$ & $\begin{array}{l}\text { Ratio of current } \\
\text { period sales and } \\
\text { management } \\
\text { expenses to that of } \\
\text { last period }\end{array}$ \\
\hline \multirow[b]{2}{*}{$\begin{array}{l}\text { Explanatory } \\
\text { variable }\end{array}$} & $\begin{array}{c}\text { Operating } \\
\text { income change } \\
\text { rate }\end{array}$ & $\frac{\text { Sales }_{i, t}}{\text { Sales }_{i, t-1)}}$ & $\begin{array}{l}\text { Ratio of current } \\
\text { period operating } \\
\text { income to that of } \\
\text { last period }\end{array}$ \\
\hline & $\begin{array}{c}\text { Manager's } \\
\text { overconfidence }\end{array}$ & Oconf & $\begin{array}{l}\text { Ratio of the top } \\
\text { three directors, } \\
\text { supervisors or } \\
\text { senior managers to } \\
\text { the entire manager } \\
\text { salary }\end{array}$ \\
\hline \multirow{3}{*}{$\begin{array}{c}\text { Control } \\
\text { Variable }\end{array}$} & $\begin{array}{l}\text { Asset } \\
\text { intensity }\end{array}$ & $\operatorname{Ain}_{i, t}$ & $\begin{array}{c}\text { Ratio of the } \\
\text { company's total } \\
\text { assets to operating } \\
\text { income }\end{array}$ \\
\hline & $\begin{array}{l}\text { Changes } \\
\text { in operating } \\
\text { income for two } \\
\text { consecutive } \\
\text { periods }\end{array}$ & SucDec $_{i, t}$ & $\begin{array}{l}\text { Take } 1 \text { when the } \\
\text { operating income } \\
\text { drops for two } \\
\text { consecutive years, } \\
\text { otherwise take } 0\end{array}$ \\
\hline & $\begin{array}{l}\text { Annual } \\
\text { fixed effect }\end{array}$ & Year & $\begin{array}{c}\text { Annual dummy } \\
\text { variable }\end{array}$ \\
\hline $\begin{array}{l}\text { Dummy } \\
\text { variable }\end{array}$ & & $\operatorname{DecrDum}_{i, t}$ & $\begin{array}{l}\text { When the operating } \\
\text { income of this year } \\
\text { is lower than last } \\
\text { year, the value is } 1 \text {, } \\
\text { otherwise it is } 0 \text {. }\end{array}$ \\
\hline
\end{tabular}

\section{Empirical analysis}

\subsection{Descriptive analysis}

It can be seen from Table 2 that, the average value of $\frac{S G A_{i, t}}{S G A_{i, t-1)}}$ is 1.133, indicating that the sales and management expenses of listed companies in the manufacturing industry have increased year by year. The average value of $\frac{\text { Sales }_{i, t}}{\text { Sales }_{i, t-1}}$ is 1.115 , indicating that average level of operating income also increases year by year. The average value of DecrDum $_{i, t}$ is 0.239 , indicating that $23.9 \%$ of the company's operating income in year is lower than last year. The average value of $\operatorname{SucDec}_{i, t}$ is 0.072, indicating that $7.2 \%$ of the company's operating income has declined for two consecutive years. This shows that most companies' business conditions are optimistic.

Table2. Descriptive analysis

\begin{tabular}{|c|c|c|c|c|c|}
\hline Variable & Obs & Mean & Std.Dev. & Min & Max \\
\hline$\frac{\text { SGA }_{i, t}}{\text { SGA }_{i, t-1)}}$ & 4359 & 1.133 & .15 & .848 & 1.661 \\
\hline$\frac{\text { Sales }_{i, t}}{\text { Sales }_{i, t-1}}$ & 4359 & 1.115 & .16 & .793 & 1.539 \\
\hline DecrDum $_{i, t}$ & 4359 & .239 & .426 & 0 & 1 \\
\hline oconf & 4359 & 41.872 & 11.685 & 14.09 & 98.19 \\
\hline Ain $_{i, t}$ & 4359 & 2.117 & 2.125 & .135 & 65.186 \\
\hline SucDec $_{i, t}$ & 4359 & .072 & .258 & 0 & 1 \\
\hline
\end{tabular}

\subsection{Correlation analysis}

Table 3 shows the results of regression analysis. The upper right and lower left corners are the Pearson coefficient and Spearman coefficient respectively. Except for the correlation coefficient of the dummy variable is -0.73 , the other correlation coefficients are all less than 0.7, indicating that there is no multicollinearity among the variables.

Table3. Descriptive analysis

\begin{tabular}{|c|c|c|c|c|c|c|}
\hline & $\ln \left(\frac{S G A_{i, t}}{S G A_{i, t-1)}}\right)$ & $\ln \left(\frac{\text { Sales }_{i, t}}{\text { Sales }_{i, t-1}}\right)$ & oconf & DecrDum $_{i, t}$ & Ain & $\begin{array}{l}\text { SucDe } \\
\text { c }\end{array}$ \\
\hline $\ln \left(\frac{S G A_{i, t}}{\left.S G A_{i, t-1}\right)}\right)$ & 1 & 0.487 & 0.019 & -0.328 & 0.004 & -0.206 \\
\hline $\ln \left(\frac{\text { Sales }_{i, t}}{\operatorname{Sales}_{i, t-1}}\right)$ & 0.468 & 1 & 0.015 & -0.738 & -0.052 & -0.371 \\
\hline oconf & 0.0132 & 0.0164 & 1 & -0.007 & -0.046 & 0.0147 \\
\hline DecrDum $_{i, t}$ & -0.307 & -0.730 & -0.01 & 1 & 0.096 & 0.497 \\
\hline $\operatorname{Ain}_{i, t}$ & -0.0075 & -0.0489 & $\overline{0} .008$ & 0.068 & 1 & 0.082 \\
\hline SucDec $_{i, t}$ & -0.193 & -0.371 & 0.012 & 0.497 & 0.0668 & 1 \\
\hline
\end{tabular}

\subsection{Multiple regression analysis}

Table 4 is the regression results of formula 1 and formula 2 , which the regression results of formula 1 are listed in column 1. It can be seen from the results that the coefficient of change in operating income is significantly positive, and indicating that sales and management 
expenses change in the same direction with operating income. Sales and management expenses increase (decrease) as operating income increases (decreases). The coefficient of change in operating income and the coefficient of dummy variables are significantly negative, then can indicating that when operating income decreases, the reduction in sales and management expenses is less than the increase in operating income. Which can prove the existence of cost stickiness. Hypothesis 1 is verified. Column 2 is the regression result after adding dummy variables of capital intensity and changes in operating income for two consecutive periods. Cost stickiness still exists. The coefficient of capital intensity $\left(\operatorname{Ain}_{i, t}\right)$ is significantly positive can indicate that the more assets the enterprise has, the higher the adjustment cost. Then the cost stickiness will be more serious. The coefficient of the dummy variable of the change in operating income for two consecutive periods $\left(\operatorname{SucDec}_{i, t}\right)$ is significantly positive which means that when the operating income of an enterprise declines for two consecutive years. The manager will reduce the resources held in time which can alleviate cost stickiness. Column 3 is the regression result of formula 2. The cost stickiness phenomenon is still verified. The regression results of $\operatorname{Ain}_{i, t}$ and $S u c D e c_{i, t}$ are the same as those in columns 1 and 2 . The coefficient of the manager's overconfidence coefficient is significantly negative, and indicate that the higher the degree of managerial overconfidence. The more serious the cost stickiness of the enterprise. Then hypothesis 2 is verified.

Table4. Multiple regression analysis

\begin{tabular}{|c|c|c|c|}
\hline & Model1 & Model 2 & Model 3 \\
\hline & $\ln \left(\frac{S G A_{i, t}}{\left.S G A_{i, t-1}\right)}\right)$ & $\ln \left(\frac{S G A_{i, t}}{\left.S G A_{i, t-1}\right)}\right)$ & $\ln \left(\frac{S G A_{i, t}}{\left.S G A_{i, t-1}\right)}\right)$ \\
\hline $\ln \left(\frac{\text { Sales }_{i, t}}{\text { Sales }_{i, t-1)}}\right)$ & $\begin{array}{l}0.520^{\cdots *} \\
(30.71)\end{array}$ & $\begin{array}{l}0.519^{\cdots *} \\
(30.73)\end{array}$ & $\begin{array}{l}0.519^{\cdots *} \\
(30.70)\end{array}$ \\
\hline DecrDum $_{i, t} \times \ln \left(\frac{\text { Sales }_{i, t}}{\text { Sales }_{i, t-1)}}\right)$ & $\begin{array}{l}-0.316 \cdots \\
(-6.39)\end{array}$ & $\begin{array}{l}-0.280^{\cdots *} \\
(-4.68)\end{array}$ & $\begin{array}{l}-0.391^{*} \\
(-2.99)\end{array}$ \\
\hline $\begin{aligned} & \operatorname{DecrDum}_{i, t} \times \ln \left(\frac{\text { Sales }_{i, t}}{\text { Sales }_{i, t-1)}}\right) \\
\times & \text { Oconf }\end{aligned}$ & - & - & $\begin{array}{c}-0.00279^{* *} \\
(0.96)\end{array}$ \\
\hline $\begin{aligned} & \operatorname{DecrDum}_{i, t} \times \ln \left(\frac{\text { Sales }_{i, t}}{\text { Sales }_{i, t-1)}}\right) \\
& \times \operatorname{Ain}_{i, t}\end{aligned}$ & - & $\begin{array}{c}-0.03666^{* \cdots} \\
(-3.67)\end{array}$ & $\begin{array}{c}-0.0366 \cdots \\
(-3.67)\end{array}$ \\
\hline $\begin{aligned} & \operatorname{DecrDum}_{i, t} \times \ln \left(\frac{\text { Sales }_{i, t}}{\text { Sales }_{i, t-1)}}\right) \\
& \times \operatorname{SucDec}_{i, t}\end{aligned}$ & - & $\begin{array}{l}0.188^{* *} \\
(2.68)\end{array}$ & $\begin{array}{l}0.184^{* \prime} \\
(2.62)\end{array}$ \\
\hline Year & Yes & Yes & Yes \\
\hline $\mathrm{Adj}-\mathrm{R}^{2}$ & 0.34 & 0.35 & 0.34 \\
\hline _cons & $\begin{array}{c}0.0649 \cdots \\
(14.95)\end{array}$ & $\begin{array}{c}0.0640^{\cdots *} \\
(14.66)\end{array}$ & $\begin{array}{l}0.0640 \cdots \\
(14.65)\end{array}$ \\
\hline$N$ & 4359 & 4359 & 4359 \\
\hline
\end{tabular}

\section{Conclusion}

Cost management plays an important role in the operation and management of an enterprise. Reasonable planning of cost expenditure is conducive to improving corporate performance and core competitiveness. Among the study of managers' overconfidence, scholars pay more attention to their business consequences, but less attention to cost decisions. This paper studies the influence of managers' overconfidence on the stickiness of cost, which is of great significance for improving the enterprise's cost management and expenditure decision. Based on the review of the existing literature, this article selects Shanghai and Shenzhen A shares manufacturing listed companies as the research object for empirical research. The research results are as follows:

Firstly, there are obvious cost stickiness issues in manufacturing listed companies. Secondly, managers' overconfidence has exacerbated the cost stickiness of enterprises. Overconfident managers will have optimistic expectations for the future due to reasons such as "better than average" effects and self-attribution bias. When the operating income declines, then the managers will be optimistic about the future and will not reduce the resources held by enterprises in a timely manner under the combined influence of the willingness mechanism $f$, financial mechanism and capability mechanism. Then, coupled with the impact of adjustment costs. On the contrary, when the operating income of an enterprise rises, managers will substantially increase the assets of the enterprise. Therefore, managers' overconfidence will deepen the problem of stickiness of enterprises' expenses.

\section{References}

1. M. C. Anderson, R. D. Banker, S. N. Janakiraman, "Are selling, general, and administrative costs 'sticky',"? J. Journal of Accounting Research, 2003, 41(1): 47-63.

2. L. W. Marcia, S. Chandra, "Additional evidence on the sticky behavior of costs," R.Working Paper, University of Texas at Arlington, 2003

3. S. Y. Wan and H. Liu, "Management self-interest, board governance and expense stickiness-from listed companies in Chinese manufacturing Empirical evidence," J. Economics and Management, 2011, 25(03): 26-32.

4. F. X. Jiang, M. Zhang, Z. F. lu, and C. D. Chen, "Manager overconfidence, business expansion and financial distress," J. Economic Research, 2009,44(01):131-143.

5. S. K. Liang, "Managers overconfidence, debt constraints and cost stickiness," J. Nankai Management Review, 2015,18(03):122-131.

6. X. Y. Wu, An empirical study of the impact of managers' overconfidence on cost stickiness, D.Zhejiang University of Commerce and Industry,2015.

7. M. Young, "Board gvernance, manager overconfidence and enterprise cost stickiness, " D. Dongbei University of Finance and Economics, 2016. 